\title{
THE ROLE OF EXPERIENTIAL LEARNING AND ENGINEERING DESIGN PROCESS IN K-12 STEM EDUCATION
}

\author{
Nguyen Tien \\ Long $^{1}$ \\ (i) Nguyen Thi \\ Hoang Yen ${ }^{2}$ \\ Nguyen Van \\ Hanh $^{3+}$
}

\author{
${ }^{1,3}$ School of Engineering Pedagogy, Hanoi University of Science and \\ Technology, Hai Ba Trung District, Hanoi, Vietnam. \\ 'Email:long.nguyentien@hust.edu.vn Tel: 84918953535 \\ 'Email:hanh.nguvenvan@hust.edu.vn Tel: 84975300198 \\ ${ }^{2}$ Faculty of Education, Vietnam National Academy of Education \\ Management (NAEM), Thanh Xuan District, Hanoi, Vietnam. \\ sEmail:nhyen60@gmail.com Tel:84913584939
}

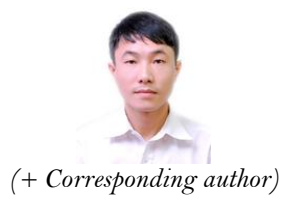

(+ Corresponding author)

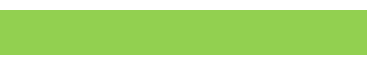

\section{Article History}

Received: 14 August 2020 Revised: 23 September 2020 Accepted: 12 October 2020 Published: 21 October 2020

\section{Keywords}

Engineering design process Experiential learning Experiential tasks

K-12 STEM education Kolb's model

STEM.

\section{ABSTRACT}

The STEM education emphasizes on Science, Technology, Engineering and Mathematics with a major focus on engineering design process that engineers require in solving challenges or problems. Kolb's model provides micro-learning activities such as experiencing, sharing and processing, generalizing and applying. Therefore, both Kolb's model and engineering design process are indispensable in K-12 STEM education. The K-12 STEM curriculum provides and guides students to complete a series of experiential tasks in engineering design process. Kolb's model explains how Science, Technology, Engineering and Mathematics are connected and integrated in each task of engineering design, while the engineering design process is an effective pedagogical approach for students to learn how to solve real problems. The purpose of this study was to explore the positive role of Kolb's model and engineering design process in K-12 STEM education from the students' perspective. The results of experimental research with 32 middle school students showed that a series of experiential tasks in engineering design process are effective activities to cultivate knowledge construction, intrinsic motivation and satisfaction of students, and stimulate students' interest in STEM fields.

Contribution/Originality: The paper is the first logical analysis of the combination of Kolb's experiential learning model and engineering design process in K12-STEM education system. The findings can act as a blueprint for educators to design interdisciplinary K12-STEM curriculum.

\section{INTRODUCTION}

The STEM education emphasizes on Science, Technology, Engineering and Mathematics with a major focus on engineering design process which engineers require in solving challenges or problems. According to National Academy of Engineering (NAE) and National Research Council (NRC) (2014), STEM education can effectively support students' awareness of the role of Science, Technology, Engineering and Mathematics in modern society. The research results of Asghar, Ellington, Rice, Johnson, and Prime (2012) show that secondary teachers feel that engineering-based hands-on activities would be particularly useful to students who wish to master math and science concepts. Margot and Kettler (2019) imply that teaching through engineering design process is an effective approach to integrate the subjects using a project-based approach as a STEM pedagogy. There are various forms of engineering design processes, but they require a cyclical process to solve a real-world problem (Margot \& Kettler, 
2019). However, secondary teachers notes that they have difficulty teaching science concepts as well when utilizing STEM in their classrooms (Dare, Ellis, \& Roehrig, 2014). These teachers expressed concerns in how STEM pedagogy is used for direct instruction of math and science concepts. STEM pedagogy requires some fundamental shifts in establishing classroom environments, and for some teachers these shifts are not always positive (Margot \& Kettler, 2019). Many high school teachers perceive the integrated nature of STEM curriculum is a challenge (Margot \& Kettler, 2019). In other words, teachers should be provided with an effective method related to instruction for individual students to integrate STEM fields. This implies that cognitive sequences may play an important role in allowing students to understand concepts of STEM fields and use them in the engineering design process. This study was conducted to fill gaps in the pedagogical knowledge base by analyzing cognitive sequences for learning STEM content.

\section{CONCEPTUAL FRAMEWORK}

Previous studies have recognized the important role of the engineering design process in STEM instruction (National Research Council (NRC), 2012). Engineering design is the key to build connections among the STEM disciplines (Kelley \& Knowles, 2016). The engineering design process allows students to use mathematics and science inquiry to create and conduct experiments for potential design solutions (Kelley \& Knowles, 2016). It also provides students the opportunity to construct new science and math knowledge through design analysis (Kelley \& Knowles, 2016). The model of engineering design process establishes the design tasks that students need to conduct to address real-world challenges as a general instructional framework of STEM education. However, previous studies have not explained the cognitive sequence of Science, Technology, Engineering, and Mathematics in each design task. Therefore, the conceptual framework of this study used experiential learning theory as a frame for cognitive sequences in STEM fields. According to Smith and Rayfield (2017), sequenced instruction with the foundation of experiential learning theory may help educators to more effectively integrate STEM concepts for students. A study by Zainal et al. (2018) showed that the STEM module and robotic prototype based on Kolb's experiential learning increased the learning efficiency of students. Using experiential learning in STEM studies also allowed students to work on meaningful hands-on activities (Pappas et al, 2018). Unfortunately, those studies did not explain the connection between experiential learning and engineering design process in STEM education.

Kolb's experiential learning theory was used for this study because it explains the learner's internal cognitive sequence. Central to Kolb's theory is a spiral of learning involving four phases of active experimentation, concrete experience, reflective observation and abstract conceptualization (Kolb, 1984). The entire cycle with a minimum of four phases must be completed in order for learning to occur. The K-12 STEM education is to help students construct scientifc understanding and real-world problem-solving skills by engaging them in an engineering design process (Ting, 2016). The importance of engineering design in K-12 STEM education is to encourage students to experience engineering with hands-on activities as a practical application of mathematics and scientific knowledge. Each hands-on activity of knowledge and skills is aligned with Kolb's experiential learning model (Ting, 2016). The role of Kolb's model in K-12 STEM education is shown in Figure 1.

Figure 1 reveals how learners construct and refine their knowledge through experimentation. Concrete experience of learners can reflect observations and generalizations. Then, newly formed concepts are tested through active experimentation. Researchers have grouped some steps to focus on three micro-activities: (1) experiencing, (2) reflecting and generalizing, (3) applying. 


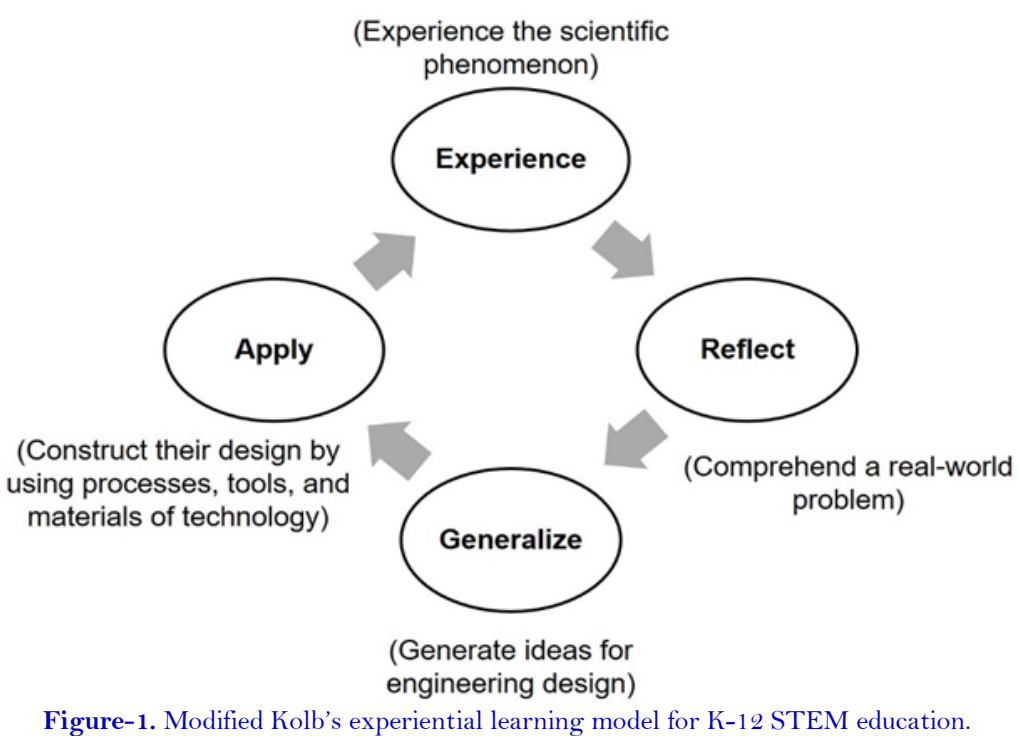

Each of these micro-activities has the different outcomes, including what suggested by National 4-H Council (2011):

- To Learn: These activities explore fundamental scientific knowledge.

- To Do: These activities focus on designing, drawing, and idea generation about engineering.

- To Make: These activities include building, constructing design, using processes, tools, and materials of technology.

Kolb's cycle guides the development of micro activities in order to integrate Science, Technology, Engineering and Mathematics in each task of the engineering design process (Ting, 2016). These phases address a common concern about hands-on activities, while students acquire the required knowledge in the STEM fields through micro-learning activities within the tasks of these phases including the engineering design task (Apedoe, Reynolds, Ellefson, \& Schunn, 2008). The role of engineering design process in K-12 STEM education is shown in Figure 2.

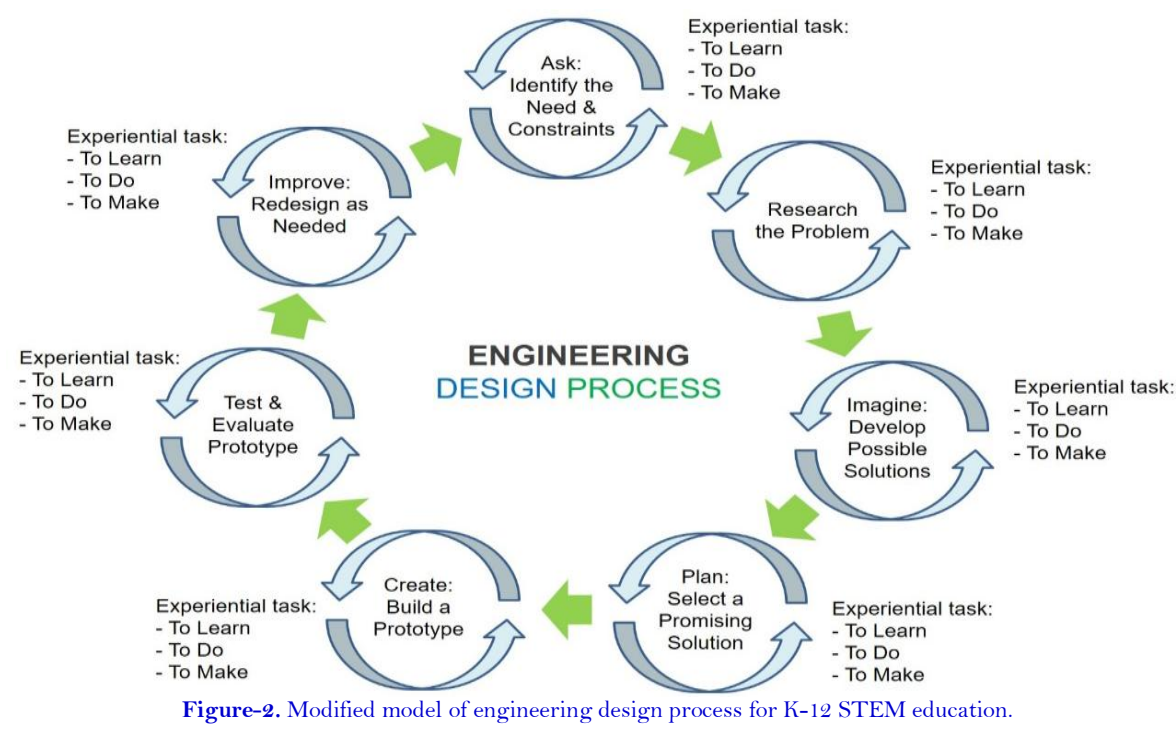

Figure 2 shows the engineering design process as a series of experiential tasks that guide students to a common concern about each step of the design process. Overarching themes of engineering design process emphasize openended problem solving, and encourages students to learn from failure and teamwork (Van Hanh, 2018). Experiencing the engineering design process nurtures students' abilities to create innovative solutions to major challenges that confront the society today (National Research Council (NRC), 2012). The implementation of 
experiential tasks requires students to work together to brainstorm new ideas, apply math and science knowledge, test prototypes and continually improve products that aim to be creative and practical in finding solutions to those challenges. The combination of Kolb's cycle and engineering design process in the K-12 STEM curriculum can significantly support and engage students' interaction, engagement, competency and interest, and foster STEM literacy (Zainal, Din, Abd Majid, Nasrudin, \& Abd Rahman 2018). In other words, engineering design is a useful pedagogical strategy for implementing the K-12 STEM education (Lucas, Claxton, \& Hanson, 2014; NAE (National Academy of Engineering) and NRC (National Research Council), 2009).

To sum up, the K-12 STEM curriculum provides and guides students to complete a series of experiential tasks in engineering design process, while Kolb's model is used to develop micro-activities in each task of engineering design. The students acquire the required knowledge in the STEM fields through micro-learning activities within the experiential tasks of engineering design process (Apedoe et al., 2008). Hence, the combination of Kolb's model and engineering design process can significantly engage students' interest in STEM fields (Zainal et al., 2018).

Table-1. Some topics for K-12 STEM curricula.

\begin{tabular}{|c|c|c|c|c|}
\hline Topics & Math and science & Engineering & Technology & CMA tools \\
\hline $\begin{array}{l}\text { Grade 6: Smart electric fan } \\
\text { - Automatic control of } \\
\text { wind speed according to } \\
\text { external environment } \\
\text { temperature. } \\
\text { - Automatic turning } \\
\text { on/off the fan when } \\
\text { detecting people coming } \\
\text { in/out. }\end{array}$ & $\begin{array}{l}\text { - The phenomenon } \\
\text { of convective heat } \\
\text { loss. } \\
\text { - Calculation and } \\
\text { measurement of } \\
\text { blade angle of fan }\end{array}$ & $\begin{array}{l}\text { - Programming } \\
\text { control/ codes } \\
\text { - Methods to } \\
\text { control fan } \\
\text { speed }\end{array}$ & $\begin{array}{l}\text { - Motor fan } 12 \mathrm{~V} \\
\text { DC } \\
\text { - Materials and } \\
\text { process for } \\
\text { making fan } \\
\text { model }\end{array}$ & $\begin{array}{l}\text { - Coach } 7 \text { software } \\
\text { - Motion detector } \\
\text { (O664) } \\
\text { - Temperature } \\
\text { sensor (BTo1) } \\
\text { - Anemometer } \\
\text { (BT15i) } \\
\text { - CoachLab II+ }\end{array}$ \\
\hline $\begin{array}{l}\text { Grade } 7 \text { : Agricultural } \\
\text { greenhouses } \\
\text { Automatic control of the } \\
\text { temperature, soil moisture, } \\
\text { light, humidity, and air in } \\
\text { the greenhouse which are } \\
\text { the most suitable for } \\
\text { growing plants. }\end{array}$ & $\begin{array}{l}\text { - Environmental } \\
\text { factors that affect } \\
\text { plant growth } \\
\text { - Calculation for } \\
\text { making greenhouse } \\
\text { frames }\end{array}$ & $\begin{array}{l}\text { - Programming } \\
\text { control/ codes } \\
\text { - The VietGAP } \\
\text { standard }\end{array}$ & $\begin{array}{l}\text { - Structure of } \\
\text { greenhouses } \\
\text { - Motor } 12 \mathrm{~V} \text { DC } \\
\text { - } 12 \mathrm{~V} \text { DC water } \\
\text { pump } \\
\text { - } 12 \mathrm{~V} \text { DC } \\
\text { ventilation fan } \\
\text { - Materials and } \\
\text { process for } \\
\text { making } \\
\text { greenhouse }\end{array}$ & $\begin{array}{l}\text { - Coach } 7 \text { software } \\
\text { - Light sensor } \\
\text { (BT50i) } \\
\text { - Temperature } \\
\text { sensor (BT84i) } \\
\text { - Humidity sensor } \\
\text { (BT72i) } \\
\text { - CoachLab II+ }\end{array}$ \\
\hline $\begin{array}{l}\text { Grade 8: Smart garden } \\
\text { lighting system } \\
\text { - Automatically turning } \\
\text { on some lights at night } \\
\text { and turning off all lights } \\
\text { in the morning. } \\
\text { - Automatically turning } \\
\text { on some more lights when } \\
\text { detecting people coming } \\
\text { in, and turning off when } \\
\text { people go out. }\end{array}$ & $\begin{array}{l}\text { - Concept of } \\
\text { illuminance (Lux) } \\
\text { - Calculation for } \\
\text { making house and } \\
\text { garden }\end{array}$ & $\begin{array}{l}\text { - Programming } \\
\text { control/ codes } \\
\text { - Garden light } \\
\text { circuit } \\
\text { schematic }\end{array}$ & $\begin{array}{l}\text { - } 12 \mathrm{~V} \text { DC light } \\
\text { bulbs and wires } \\
\text { - Materials and } \\
\text { process for } \\
\text { making house } \\
\text { and garden }\end{array}$ & $\begin{array}{l}\text { - Coach } 7 \text { software } \\
\text { - Light sensor } \\
\text { (BT50i) } \\
\text { - Motion detector } \\
\text { (O664) } \\
\text { - CoachLab II+ }\end{array}$ \\
\hline $\begin{array}{l}\text { Grade 9: Smart desk lamp } \\
\text { - Automatically adjusting } \\
\text { the light according to the } \\
\text { surrounding environment. } \\
\text { - Dim light at night for } \\
\text { better sleep. } \\
\text { - Automatically turning } \\
\text { on light when detecting } \\
\text { people coming in, and } \\
\text { turning off when people } \\
\text { go out. }\end{array}$ & $\begin{array}{l}\text { - Concept of } \\
\text { luminance (Lux) } \\
\text { - Outdoor } \\
\text { luminance levels } \\
\text { - Calculation for } \\
\text { making desk lamp }\end{array}$ & $\begin{array}{l}\text { - Programming } \\
\text { control/ codes } \\
\text { - Office lighting } \\
\text { standards }\end{array}$ & $\begin{array}{l}\text { - Desk lamp } \\
\text { patterns } \\
\text { - 12V DC light } \\
\text { bulbs and wires } \\
\text { - Materials and } \\
\text { process for } \\
\text { making desk } \\
\text { lamp }\end{array}$ & $\begin{array}{l}\text { - Coach } 7 \text { software } \\
\text { - Light sensor } \\
\text { (BT50i) } \\
\text { - Motion detector } \\
\text { (O664) } \\
\text { - Sound sensor } \\
\text { (BT80i) } \\
\text { - CoachLab II+ }\end{array}$ \\
\hline
\end{tabular}




\section{MATERIAL INFORMATION}

\subsection{Materials}

According to Moore et al. (2014), there are two main types of integration of K-12 STEM education, including: (1) content integration - focusing on the merging of content fields into a single curriculum; (2) context integration focusing on the content of one discipline and using contexts from others to make the content more interesting. In this study, the first type of STEM education was used to develop K-12 STEM curriculum (grades 6, grade 7, grade 8, and grade 9). They were designed as interdisciplinary STEM curriculum (Mayes, Gallant, \& Fettes, 2018).

In 2018, under the auspices of Hanoi Education Book Joint Stock Company - HAEBCO (a member of Vietnam Education Publishing House Limited Company), we developed four K-12 STEM curricula (Table-1). HAEBCO supported us with the modern educational technology of CMA (Center for Microcomputer Applications) of the University of Amsterdam, Netherlands. For all K-12 STEM topics, we made the most of CMA technologies to provide students with tangible experiences in a digital LAB environment.

The instructor also planned and organized a series of experiential tasks for students during their engineering design process in a digital LAB environment. In each task, CMA tools were used to help students access and practice knowledge and skills in the all STEM fields in a meaningful way. Additionally, CMA tools provided instructors with effective ideas to design "To Learn, To Do, and To Make" activities for students.

Table 2 below summarizes the instructional plan for 6th grade STEM with the topic - "Smart electric fan"

Table-2. A summary of instructional plan for 6th grade STEM with the topic - "Smart electric fan".

\section{K-12 STEM topic: Smart electric fan}

Objectives: By the end of the topic, students will be able to:

- Select a design solution for smart electric fans with CMA sensors.

- Make a smart electric fan.

- Write code programming in Coach 7 and activate sensors.

- $\quad$ Set and test the control parameters.

- Share creative ideas in design.

\begin{tabular}{|c|c|c|c|}
\hline \multicolumn{4}{|l|}{$\begin{array}{l}\text { Time required: } 3 \text { hours } \\
\text { Group size: } 8 \text { students }\end{array}$} \\
\hline Experiential tasks & To Learn & To Do & To Make \\
\hline $\begin{array}{l}\text { 1. How do fans make you feel } \\
\text { cooler? }\end{array}$ & $\begin{array}{l}\text { - Experience } 90 \% \\
\text { alcohol evaporation } \\
\text { with body }\end{array}$ & $\begin{array}{l}\text { - How the wind } \\
\text { increases convective } \\
\text { heat loss }\end{array}$ & $\begin{array}{l}\text { - Discuss the structure } \\
\text { of electric fan }\end{array}$ \\
\hline $\begin{array}{l}\text { 2. How much is the fan's wind } \\
\text { speed suitable for the human } \\
\text { body? }\end{array}$ & $\begin{array}{l}\text { - Measure wind speed } \\
\text { with BT15i sensor } \\
\text { - Measure temperature } \\
\text { with BTo1 sensor }\end{array}$ & $\begin{array}{l}\text { - Make a table of } \\
\text { wind and } \\
\text { temperature ratios } \\
\text { that you feel } \\
\text { comfortable }\end{array}$ & $\begin{array}{l}\text { - Definition of the } \\
\text { problem for smart fan }\end{array}$ \\
\hline $\begin{array}{l}\text { 3. What ideas do you have to } \\
\text { make electric fan smarter? }\end{array}$ & $\begin{array}{l}\text { - Measure the distance } \\
\text { between human body } \\
\text { and table fan. }\end{array}$ & $\begin{array}{l}\text { - Read catalog of } \\
\text { BTo1 and } 0664 \\
\text { sensors }\end{array}$ & $\begin{array}{l}\text { - Discuss sensor } \\
\text { solutions }\end{array}$ \\
\hline $\begin{array}{l}\text { 4. How do we make a table } \\
\text { fan? }\end{array}$ & $\begin{array}{l}\text { - Measure blade angle } \\
\text { of fan }\end{array}$ & $\begin{array}{l}\text { - Read a diagram of } \\
\text { table fan }\end{array}$ & - Make a table fan \\
\hline $\begin{array}{l}\text { 5. How do you make table fan } \\
\text { smarter? }\end{array}$ & $\begin{array}{l}\text { - Learn about CMA } \\
\text { code }\end{array}$ & $\begin{array}{l}\text { - Write code } \\
\text { programming in } \\
\text { Coach } 7\end{array}$ & $\begin{array}{l}\text { - Assemble CoachLab } \\
\text { II+ with sensors, fan } \\
\text { and computer }\end{array}$ \\
\hline 6. Test and evaluate table fan & $\begin{array}{l}\text { - Measure wind speed } \\
\text { with BT15i sensor }\end{array}$ & $\begin{array}{l}\text { - Set and test the } \\
\text { control parameters }\end{array}$ & $\begin{array}{l}\text { - Adjust blade angle of } \\
\text { fan }\end{array}$ \\
\hline 7. Public demonstration & $\begin{array}{l}\text { - Oral presentation of } \\
\text { idea }\end{array}$ & - Demonstrate result & $\begin{array}{l}\text { - Feedback } \\
\text { improvement }\end{array}$ \\
\hline
\end{tabular}

A brief explanation of the lecture procedure is given below:

1. Introduction: Course outline, procedure, expectations, etc. (15 minutes).

2. Classroom management: Teamwork selection, time management, Lab. rules (15 minutes). 
3. Experience design: detailed description of what students experience to learn, to do and to make in the experiential task in a design process. Then, the student team implements the task through the instructional materials. (2 hours).

4. Sharing and evaluation: Team evaluation, public demonstration, technical report (30 minutes).

\subsection{Research Questions}

The purpose of this study was to explore the positive role of Kolb's model and engineering design process in K12 STEM education by students' perspective. The researchers defined two research questions, namely:

1. How has the use of a series of experiential tasks in engineering design process impacted students' STEM learning outcomes?

This question highlights the premise that stated by Kintu, Zhu, and Kagambe (2017), according to which intrinsic motivation, satisfaction and knowledge construction are the main factors in learning outcomes of students. Freeman, Alston, and Winborne (2008), too, indicate that learning communities positively influence students' attitudes, intrinsic motivation and learning experiences in STEM. The aspects of the students' intrinsic motivation in STEM fields, including enjoyment of their STEM courses, their perceived competence in STEM, and the pressure they felt in STEM classes, all of which are related to students' STEM learning outcomes (Ramsey, Betz, \& Sekaquaptewa, 2013). Attention and motivation are important components in inspiring students to pursue STEM learning (National Research Council (NRC), 2009). Elhadary (2016) indicates that students' perception of the meaning of the program/course content, the availability of technology internship, and satisfaction with teaching interaction, all contributed to students' overall satisfaction with STEM education.

2. How has the use of a series of experiential tasks in engineering design process stimulated students' interest in STEM fields?

This research question also relates to the premise stated by VanMeter-Adams, Frankenfeld, Bases, Espina, and Liotta (2014), who reported extracurricular encounters (such as the influence of family member and childhood experiences) as the most significant factors that initially ignited their interest in STEM. Hands-on laboratory experiences in the 'STEM Labs' correlated with a perceived sustained interest in pursuing STEM-related academic degrees and employment of students (VanMeter-Adams et al., 2014). The students who show a strong interest in STEM, they are most influenced by extracurricular experiences to become interested in STEM (VanMeter-Adams et al., 2014; Walan \& Gericke, 2019).

\section{METHODOLOGY}

\subsection{Theoretical approach}

The researchers used an experimental design to explore the positive role of Kolb's model and engineering design process in K-12 STEM education from students' perspective. To examine how participation in a K-12 STEM curriculum influences students' perception of STEM learning, we used self-perception theory of Bem (1972). The self-perception theory allows researchers to focus on attitude formation and change of student participants in an experimental environment (Bem, 1972). Such a theoretical lens allows us to examine the attitude towards STEM caused by their own new experiences in the context of STEM experiment.

Laird and Bresler (1992) used this self-perception theory to explore the process of emotional experience and drew following three conclusions: first, emotional feelings do follow from, or rather lead, emotional actions; second, people differ in the degree to which their emotional feelings are products of their own actions or based on information from situations which they find themselves in; third, the same process that generates emotional experiences also produces other feelings. Therefore, the researchers argue that clarifying the positive role of Kolb's model and engineering design process in K-12 STEM education could positively impact students' perception in 
STEM fields. Kolb's model explains how Science, Technology, Engineering And Mathematics are connected and integrated together, while the engineering design process proves to be an effective pedagogical approach for students to learn solving real problems. This is expected to positively affect students' perception in STEM.

\subsection{Participants}

The sample of the study included 32 middle school students who were selected to participate in the experiment, classified in groups as below:

- Group 1: Eight students of grade 6 to participate in STEM topic "Smart electric fan".

- Group 2: Eight students of grade 7 to participate in STEM topic "Agricultural greenhouses".

- Group 3: Eight students of grade 8 to participate in STEM topic "Smart garden lighting system".

- Group 4: Eight students of grade 9 to participatein STEM topic "Smart desk lamp”.

Participants were selected based on the following three criteria:

- Participation in the course was voluntary;

- Students did not know about K-12 STEM topics which they experienced in experiment;

- Students who had a prior experience of other STEM courses.

The experiment was conducted in April, 2019 at K-12 STEM laboratory of HAEBCO (Figure 3).

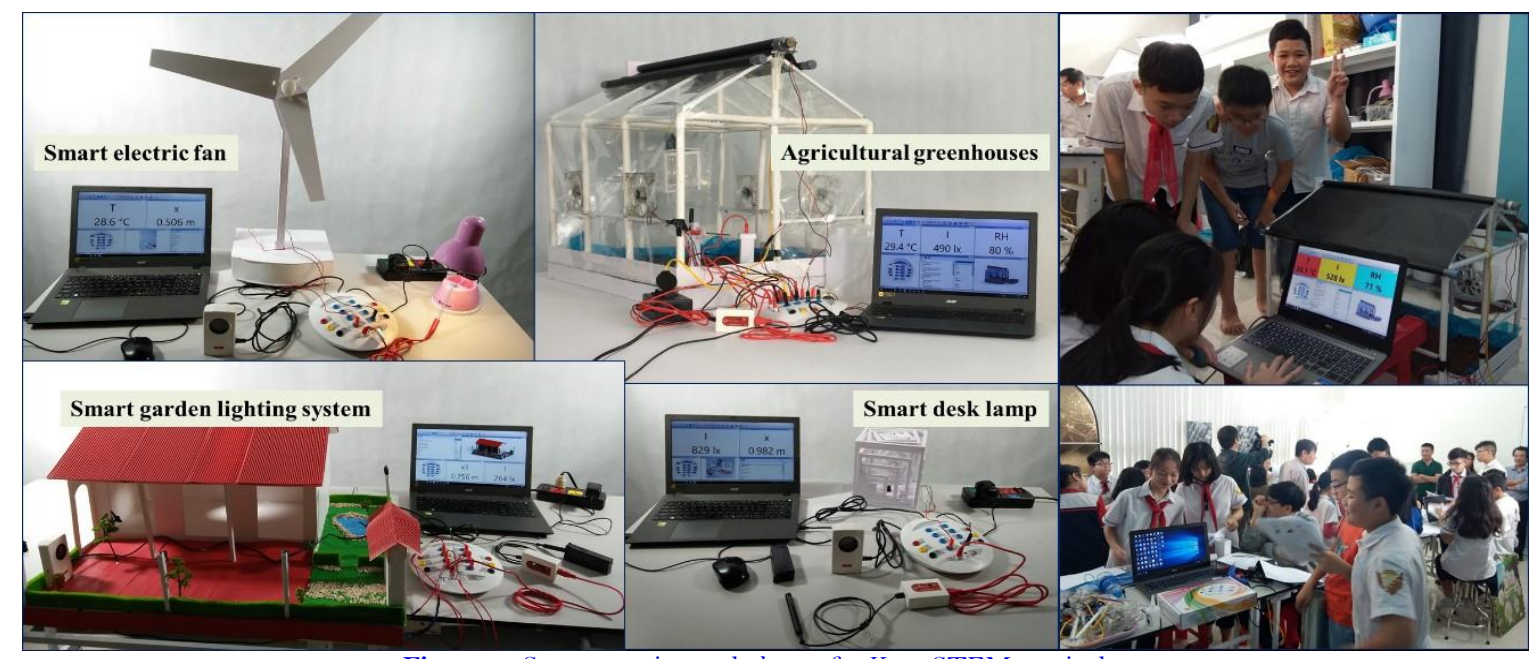

Figure-3. Some experimental photos for K-12 STEM curriculum.

\subsection{Data collection}

At the end of the experiment, we delivered direct questionnaires to students to collect their responses on the positive role of Kolb's model and engineering design process in K-12 STEM education. All surveys were anonymous. The data was collected on STEM learning outcomes of students. The closed-ended questions were used to collect quantitative data, while qualitative data was collected with open-ended questions.

The close-ended questions used the five-point Likert scale, because the survey items focused on evaluating levels in students' perspective on STEM learning outcomes (Sullivan \& Artino, 2013). The following nine questions formed the questionnaire:

1. Did I learn math and science concepts more effectively than the STEM courses I took before?

2. Did I apply math and science concepts to solve a real-world problem more effectively than the STEM courses I took before?

3. Did I make practical applications of math, science, and engineering content in order to solve our challenges more effectively than the STEM courses I took before?

4. Were the experiential tasks in engineering design process more enjoyable and interesting than the STEM courses I took before? 
5. Did the experiential tasks in engineering design process have a positive impact on my perception competence about STEM when compared to the STEM courses I took before?

6. Did the experiential tasks in engineering design process have a positive impact on my persistence and effort to solve complex problems when compared to the STEM courses I took before?

7. Was the course content more explicitly and tightly connected than the STEM courses I took before?

8. Were the technology-based hands-on activities more available than the STEM courses I took before?

9. Were teaching and group interactions more interesting than the STEM courses I took before?

The open-ended questions in the questionnaire aimed to collect data on students' interest in K12-STEM curriculum. This approach allowed students to explain in more detail their interest in the K12-STEM topic. The questionnaire contained three direct questions: Do you want to follow similar STEM curriculum in future? Why? and What do you propose to improve?

\subsection{Data Analysis}

- For close-ended questions used answers ranged from " $1=$ strongly disagree" to " $5=$ strongly agree"): The five-point Likert scale had 4 intervals and 5 categories with the ratio $4 / 5$ being equal to "0.8”. We suggested that the mean score of " 3.4 " could be determined as the minimum level of success in K-12 STEM curriculum. Additionally, the mean score of "4.2" was determined as the most successful level of learning outcomes in K12 STEM curriculum (Van Hanh, 2018).

Table-3. Reliability results for the instrument on the STEM learning outcomes of students.

\begin{tabular}{|c|c|c|c|}
\hline Items & $\begin{array}{l}\text { Corrected } \\
\text { Item-Total } \\
\text { Correlation }\end{array}$ & $\begin{array}{l}\text { Cronbach's } \\
\text { Alpha if Item } \\
\text { Deleted }\end{array}$ & $\begin{array}{l}\text { Cronbach's } \\
\text { Alpha }\end{array}$ \\
\hline \multicolumn{4}{|l|}{$\begin{array}{l}\text { The experiential tasks in engineering design process in } \\
\text { STEM education are very effective activities: }\end{array}$} \\
\hline - $\quad$ To learn math and science concepts. & 0.63 & 0.56 & \multirow{3}{*}{0.74} \\
\hline $\begin{array}{l}\text { - To apply math and science concepts to solve a } \\
\text { real-world problem through engineering design. }\end{array}$ & 0.50 & 0.72 & \\
\hline $\begin{array}{l}\text { - To make practical applications of math, science, } \\
\text { and engineering content in order to solve real } \\
\text { challenges. }\end{array}$ & 0.55 & 0.66 & \\
\hline \multicolumn{4}{|l|}{$\begin{array}{l}\text { The experiential tasks in engineering design process in } \\
\text { STEM education are very effective activities for } \\
\text { developing: }\end{array}$} \\
\hline - Interest and enjoyment about STEM learning. & 0.71 & 0.86 & \multirow{3}{*}{0.87} \\
\hline $\begin{array}{l}\text { - Perception competence to understand the } \\
\text { connectedness of science, technology, engineering, } \\
\text { and mathematics in STEM. }\end{array}$ & 0.82 & 0.75 & \\
\hline $\begin{array}{l}\text { - Persistence and effort to solve complex problems } \\
\text { on STEM challenges. }\end{array}$ & 0.74 & 0.83 & \\
\hline \multicolumn{4}{|l|}{$\begin{array}{l}\text { The experiential tasks in engineering design process in } \\
\text { STEM education are enjoyable experience as: }\end{array}$} \\
\hline $\begin{array}{l}\text { - The course content is explicitly and tightly } \\
\text { connected. }\end{array}$ & 0.49 & 0.72 & \multirow{3}{*}{0.73} \\
\hline $\begin{array}{l}\text { - The technology-based hands-on activities are } \\
\text { available (especially CMA tools and Coach 7). }\end{array}$ & 0.48 & 0.71 & \\
\hline - $\quad$ Teaching and group interactions are interesting. & 0.70 & 0.47 & \\
\hline \multicolumn{4}{|c|}{$N=32$, Cronbach's Alpha value $>0.7$, Corrected Item - Total Correlation value $>0.3$} \\
\hline
\end{tabular}

Three Cronbach Alpha tests were conducted to determine the reliability of data on the STEM learning outcomes of students (Table 3). According to Cortina (1993) a Cronbach's alpha value of higher than 0.70 does reflect internal consistency instead of irrelevancies like in case of number of items. In all cases, the Cronbach's 
Alpha values were greater than "0.7". For all items, the Corrected Item - Total Correlation values were greater than "0.3", and the Cronbach's Alpha of Item Deleted values were less than the Cronbach's Alpha value. So, internal consistency reliability was accepted on all scales.

For open-ended questions, the responses were submitted in writing. A content analysis was done of all these responses to K-12 STEM curriculum to arrive at the results.

\section{RESULTS}

Question 1: How has the use of a series of experiential tasks in engineering design process impacted students' STEM learning outcomes?

Three Friedman tests in SPSS were conducted to observe the learning outcomes in K-12 STEM curriculum (Table 4). The results of Friedman test showed two main aspects of students' perspective for learning outcomes.

- First aspect: The mean score of all items was much greater with the minimum score of "3.4", which determined the level of success of K-12 STEM curriculum. Overall, the students reacted very favorably to the use of a series of experiential tasks in engineering design process. The students had agreed that the experiential tasks in engineering design process in STEM education were very effective activities to cultivate all three groups of learning outcomes including knowledge construction (mean $=4.23$ ), intrinsic motivation $($ mean $=4.25)$, and satisfaction $($ mean $=4.30)$.

Table-4. Students' perspective for STEM learning outcomes

\begin{tabular}{|c|c|c|c|}
\hline Groups & Item $^{\mathrm{a}, \mathrm{b}}$ & Mean \pm SD $^{c}$ & p-value ${ }^{d}$ \\
\hline & $\begin{array}{l}\text { The experiential tasks in engineering design process } \\
\text { effective activities: }\end{array}$ & in STEM ec & n are very \\
\hline \multirow{4}{*}{$\begin{array}{l}\text { Knowledge } \\
\text { construction } \\
(4.23 \pm 0.52)\end{array}$} & To learn math and science concepts. & $4.28 \pm 0.63$ & \multirow[t]{3}{*}{0.005} \\
\hline & $\begin{array}{l}\text { To apply math and science concepts to solve a real- } \\
\text { world problem through engineering design. }\end{array}$ & $4.00 \pm 0.62$ & \\
\hline & $\begin{array}{l}\text { To make practical applications of math, science, and } \\
\text { engineering content in order to solve real challenges. }\end{array}$ & $4.41 \pm 0.67$ & \\
\hline & \multicolumn{3}{|c|}{$\begin{array}{l}\text { The experiential tasks in engineering design process in STEM education are very } \\
\text { effective activities for developing: }\end{array}$} \\
\hline \multirow{4}{*}{$\begin{array}{l}\text { Intrinsic } \\
\text { motivation } \\
(4.25 \pm 0.64)\end{array}$} & Interest and enjoyment about STEM learning. & $4.41 \pm 0.67$ & \multirow[t]{3}{*}{0.024} \\
\hline & $\begin{array}{l}\text { Perception competence to understand the } \\
\text { connectedness of science, technology, engineering, and } \\
\text { mathematics in STEM. }\end{array}$ & $4.22 \pm 0.75$ & \\
\hline & $\begin{array}{l}\text { Persistence and effort to solve complex problems on } \\
\text { STEM challenges. }\end{array}$ & $4.13 \pm 0.75$ & \\
\hline & \multicolumn{3}{|c|}{$\begin{array}{l}\text { The experiential tasks in engineering design process in STEM education are enjoyable } \\
\text { experience as: }\end{array}$} \\
\hline \multirow{3}{*}{$\begin{array}{l}\text { Satisfaction } \\
(4.30 \pm 0.41)\end{array}$} & The course content is explicitly and tightly connected. & $4.16 \pm 0.57$ & \multirow[t]{3}{*}{0.022} \\
\hline & $\begin{array}{l}\text { The technology-based hands-on activities are available } \\
\text { (especially CMA tools and Coach } 7 \text { ). }\end{array}$ & $4.44 \pm 0.50$ & \\
\hline & Teaching and group interactions are interesting. & $4.28 \pm 0.46$ & \\
\hline \multicolumn{4}{|c|}{$\begin{array}{l}\text { Note: } \\
\text { a N }=32 . \\
\text { b Strongly disagree }=1 \text {, Disagree }=2, \text { Neutral }=3 \text {, Agree }=4 \text {, Strongly agree }=5 . \\
\text { c Standard Deviation. } \\
\text { d Friedman Test }(\mathrm{p}<0.05) .\end{array}$} \\
\hline
\end{tabular}

- Second aspect: Values of $\mathrm{p}<0.05$ in all three variable groups indicated the difference in the mean scores of learning outcomes in STEM curriculum. The high scores (mean $>4.2$ ) suggests that students agreed that experiential tasks in engineering design process were very effective activities to learn math and science concepts ("To Learn"), and to make practical applications of math, science, and engineering content in order to solve real challenges (“To Make”).

Additionally, students also agreed that the experiential tasks were very effective activities to cultivate their interest and enjoyment, and perception competence about STEM. The experiential tasks were enjoyable experience 
about technology and interaction. In the K-12 STEM laboratory space, students agreed that engineering knowledge, persistence and effort, satisfaction with course content in STEM curriculum were slightly more limited than other factors $($ mean $<4.2)$.

\section{Question 2: How has the use of a series of experiential tasks in engineering design process stimulated students' interest in STEM curriculum?}

The open ended questions were used for students to express their interest in other similar STEM curricula. We asked students to provide suggestions for improving future STEM sessions. The most common suggestions of students are listed in Table 5 .

Table-5. Students' responses after K-12 STEM curriculum.

\begin{tabular}{l} 
Question: Do you want to follow similar STEM curriculum in future? Why? What do you propose \\
to improve? \\
\hline - "Yes, I do. STEM is an enjoyable experience. Everyone in my group is excited and motivated in \\
the task of engineering design." \\
- "Yes, I am sure to follow. As I enjoy tinkering with CMA tools. I learn a lot." \\
- "I want to know and do more about programming code in Coach 7. It stimulates me to brainstorm \\
- "Scientific experience with sensors is really interesting." \\
- "Yes, I do. I would like to build a complete product by myself. It is not too difficult for me. It is \\
- "Ynderstandable if I follow the instructions provided. I am really interested in this technology." \\
- "Yes, I do. The task of engineering design is a positive challenge for me." \\
before." \\
-I would like to propose integrating science, engineering and technology into a single subject." \\
"I am sure to follow. I wish I could have a field trip to see clearer real-world problems which we \\
simulated in this LAB."
\end{tabular}

Overall, students stated that STEM curriculum was very interesting, and they were interested in experiencing more about STEM. Students also stated positive reactions to CMA technology, which supported fostering STEM education. Students proposed the desire for field trips to explore real-world problems by using CMA tools, which would enhance understanding of the meaning of engineering before implementing STEM learning in the laboratory.

\section{DISCUSSION}

The experimental results of this study clearly explained the significance of a learning theory combined with a pedagogical strategy in STEM education. In other words, findings of the study show that both Kolb's model and engineering design process are indispensable in K-12 STEM education. The results of this study provide additional support to NAE (National Academy of Engineering) and NRC (National Research Council) (2009) which implied that "engineering design is a potentially useful pedagogical strategy" (p. 4). And this result also supports the conclusion of Zainal et al. (2018) that Kolb's model is a fundamental theory in STEM learning, which explains the internal cognitive processes of learners. In addition, we use Kolb's model to further explain how the knowledge of science, mathematics and technology are embedded in engineering design process, which were not clarified by Zainal et al. (2018).

STEM learning integration is therefore no longer ambiguous; it is very vivid and clear in activities "To Learn, To Do, and To Make". The results in show that students give the excellent score for learning outcomes in their STEM session. With our theoretical model and experimental results, we doubted the results of Zainal et al. (2018) when they only used "Kolb-based STEM Module and Robotic Prototype" with five key educational activities which included watching videos, 
reading modules, assembling robotic components, drag and drop using blockly software and lastly playing a robotic game. They did not explain how science, math and technology knowledge are used in engineering design process.

The results in Table- 5 show that students are 'imbued' with the senses of curiosity in STEM learning by using CMA tools. They are like prototypes of scientists, engineers, and creators who are willing to explore and solve world problems. The experiential tasks in engineering design process actually stimulate students' interest in STEM fields, which is similar to the findings from Connor, Karmokar, and Whittington (2015). In order for K-12 STEM education to be more internalized and effectively adopted in classroom, students should be exposed to positive and authentic STEM learning experiences as early as preschool and throughout their educational pathways (Moomaw \& Davis, 2010). In addition, if students have the opportunity to experience field trips to explore real-world problems by using CMA tools, it will stimulate students' intrinsic motivation more in STEM learning (Hanh \& Hop, 2018).

\section{CONCLUSION}

This study has presented a notion of K-12 STEM education, in which both Kolb's model and engineering design process are indispensable. Kolb's cycle is used to develop micro-activities in each task of engineering design, while the engineering design process is meaningful as a pedagogical strategy for implementing the K-12 STEM education (NAE (National Academy of Engineering) and NRC (National Research Council), 2009). The findings of the experimental study show that the use of a series of experiential tasks in engineering design process are very effective activities to cultivate about knowledge construction, intrinsic motivation, and satisfaction of students. The use of Kolb's model in engineering design process stimulated more students' interest in STEM fields. In addition, the combination of Kolb's model and the engineering design process is the key to solving teachers' difficulties in designing STEM activities, which is concluded in Daher and Shahbari (2020).

This limitations of the study included (1) K-12 STEM lab space, (2) sensor-use skills, and (3) code programming skills in Coach 7 by students when they experience for the first time. It is recommended that the conceptual framework of K-12 STEM education formed from the integration of Kolb's model in engineering design process should be explored further in terms of curriculum development and pedagogical research.

Funding: This study received no specific financial support.

Competing Interests: The authors declare that they have no competing interests.

Acknowledgement: The authors acknowledged the support of Hanoi Education Book Joint

Stock Company (HAEBCO) to this study. HAEBCO has office address at M Floor of $21 \mathrm{~B} 6$

Green Star Building - No. 234 Pham Van Dong, Co Nhue Ward, Bac Tu Liem District, Hanoi,

Vietnam.

\section{REFERENCES}

Apedoe, X. S., Reynolds, B., Ellefson, M. R., \& Schunn, C. D. (2008). Bringing engineering design into high school science classrooms: The heating/cooling unit. Journal of Science Education and Technology, 17(5), 454-465.Available at: https://doi.org/10.1007/s10956-008-9114-6.

Asghar, A., Ellington, R., Rice, E., Johnson, F., \& Prime, G. M. (2012). Supporting STEM education in secondary science contexts. The Interdisciplinary Journal of Problem-Based Learning, 6(2), 85-125.Available at: https://doi.org/10.7771/1541-5015.1349.

Bem, D. J. (1972). Self-perception theory. Advances in Experimental Social Psychology, 6(1), 1-62.

Connor, A., Karmokar, S., \& Whittington, C. (2015). From STEM to STEAM: Strategies for enhancing engineering \& technology education. International Journal of Engineering Pedagogy, 5(2), 37-47.Available at: http://dx.doi.org/10.3991/ijep.v5i2.4458. 
Cortina, J. M. (1993). What is coefficient alpha? An examination of theory and applications. Journal of Applied Psychology, 78(1), 98-104.Available at: https://doi.org/10.1037/0021-9010.78.1.98.

Daher, W., \& Shahbari, J. A. (2020). Design of STEM activities: Experiences and perceptions of prospective secondary school teachers. International Journal of Emerging Technologies in Learning (iJET), 15(04), 112-128.Available at: https://doi.org/10.3991/ijet.v 15i04.11689.

Dare, E. A., Ellis, J. A., \& Roehrig, G. H. (2014). Driven by beliefs: Understanding challenges physical science teachers face when integrating engineering and physics. Journal of Pre-College Engineering Education Research, 4(2), 47-61.Available at: https://doi.org/10.7771/2157-9288.1098.

Elhadary, O. (2016). Gender and other determinants of undergraduate student satisfaction in STEM. International Journal of Learning, Teaching and Educational Research, 15(3), 256-264.

Freeman, K. E., Alston, S. T., \& Winborne, D. G. (2008). Do learning communities enhance the quality of students' learning and motivation in STEM? The Journal of Negro Education, 77(3), 227-240.

Hanh, N. V., \& Hop, N. H. (2018). The effectiveness of the industrial field trip in introduction to engineering: A case study at Hung Yen University of Technology and Education, Vietnam. International Journal of Electrical Engineering Education, 55(3), 273-289.Available at: https://doi.org/10.1177/0020720918773050.

Kelley, T. R., \& Knowles, J. G. (2016). A conceptual framework for integrated STEM education. International Journal of STEM Education, 3(1), 11.Available at: https://doi.org/10.1186/s40594-016-0046-Z

Kintu, M. J., Zhu, C., \& Kagambe, E. (2017). Blended learning effectiveness: The relationship between student characteristics, design features and outcomes. International Journal of Educational Technology in Higher Education, 14(1), 7.Available at: https://doi.org/10.1186/s41239-017-0043-4.

Laird, J. D., \& Bresler, C. (1992). The process of emotional experience: A self-perception theory. In M. S. Clark (Ed.), Review of personality and social psychology, No. 13. Emotion (pp. 213-234): Sage Publications, Inc.

Lucas, B., Claxton, G., \& Hanson, J. (2014). Thinking like an engineer: Implications for the education system: Royal Academy of Engineering. Retrieced from: www.raeng.org.uk/thinkinglikeanengineer.

Margot, K. C., \& Kettler, T. (2019). Teachers' perception of STEM integration and education: A systematic literature review. International Journal of STEM Education, 6(1), 2.Available at: https://doi.org/10.1186/s40594-018-0151-2.

Mayes, R., Gallant, B., \& Fettes, E. (2018). Interdisciplinary STEM through engineering design-based reasoning. International Journal of Engineering Pedagogy, 8(3), 60-68.Available at: https://doi.org/10.3991/ijep.v8i3.8026.

Moomaw, S., \& Davis, J. A. (2010). STEM comes to preschool. YC Young Children, 65(5), 12-14.

Moore, T. J., Stohlmann, M. S., Wang, H. H., Tank, K. M., Glancy, A. W., \& Roehrig, G. H. (2014). Implementation and integration of engineering in K-12 STEM education. In Engineering in Pre-College Settings: Synthesizing Research, Policy, and Practices (pp. 35-60): Purdue University Press.

NAE (National Academy of Engineering) and NRC (National Research Council). (2009). Engineering in K-12 education: Understanding the status and improving the prospects. L. Katehi, G. Pearson, and M. Feder. Washington, D.C: The National Academies Press.

National 4-H Council. (2011). 4-H robotics: Engineering for today and tomorrow. Junk Drawer Robotics. Retrieved from: https://4-h.org/wp-content/uploads/2016/02/FacilitatingJunkDrawerRobotics.pdf.

National Academy of Engineering (NAE) and National Research Council (NRC). (2014). STEM integration in K-12 education: Status, prospects, and an agenda for research. In M. Honey, G. Pearson, \& H. Schweingruber (Eds.), Committee on K-12 engineering education. Washington, DC: National Academies Press.

National Research Council (NRC). (2009). Learning science in informal environments: People, places, and pursuits. Washington, DC: The National Academies Press.

National Research Council (NRC). (2012). A framework for K-12 science education: Practices, crosscutting concepts, and core ideas. Committee on a Conceptual Framework for New K-12 Science Education Standards. Board on Science Education, Division of Behavioral and Social Sciences and Education. Washington, DC: The National Academies Press. 
Pappas, I. O., Mora, S., Jaccheri, L., \& Mikalef, P. (2018, April). Empowering social innovators through collaborative and experiential learning. In 2018 IEEE Global Engineering Education Conference (EDUCON) (pp. 1080-1088). IEEE.Available at:https://doi.org/10.1109/EDUCON.2018.8363350

Ramsey, L. R., Betz, D. E., \& Sekaquaptewa, D. (2013). The effects of an academic environment intervention on science identification among women in STEM. Social Psychology of Education, 16(3), 377-397.Available at: https://doi.org/10.1007/s1 1218-013-9218-6.

Smith, K. L., \& Rayfield, J. (2017). A Quasi-Experimental Examination: Cognitive Sequencing of Instruction Using Experiential Learning Theory for STEM Concepts in Agricultural Education. Journal of Agricultural Education, 58(4), 175191.Available at: https://doi.org/10.5032/jae.2017.04175

Sullivan, G. M., \& Artino, A. R. (2013). Analyzing and interpreting data from Likert-type scales. Journal of Graduate Medical Education, 5, 541-542.Available at: https://doi.org/10.4300/JGME-5-4-18.

Ting, Y.-L. (2016). STEM from the perspectives of engineering design and suggested tools and learning design. Journal of Research in STEM Education, 2(1), 59-71.

Van Hanh, N. (2018). The real value of experiential learning project through contest in engineering design course: A descriptive study of students' perspective. International Journal of Mechanical Engineering Education, 0306419018812659.Available at: https://doi.org/10.1177/0306419018812659.

VanMeter-Adams, A., Frankenfeld, C. L., Bases, J., Espina, V., \& Liotta, L. A. (2014). Students who demonstrate strong talent and interest in STEM are initially attracted to STEM through extracurricular experiences. CBE-Life Sciences Education, 13(4), 687-697.Available at: https://doi.org/10.1187/cbe.13-11-0213.

Walan, S., \& Gericke, N. (2019). Factors from informal learning contributing to the children's interest in STEM-experiences from the out-of-school activity called Children's University. Research in Science \& Technological Education, 121.Available at: https://doi.org/10.1080/02635143.2019.1667321.

Zainal, N. F. A., Din, R., Abd Majid, N. A., Nasrudin, M. F., \& Abd Rahman , A. H. (2018). Primary and secondary school students perspective on Kolb-based STEM module and robotic prototype. International Journal on Advanced Science, Engineering and Information Technology, 8(4-2), 1394-1401.Available at: http://dx.doi.org/10.18517/ijaseit.8.4-2.6794.

Views and opinions expressed in this article are the views and opinions of the author(s), International Journal of Education and Practice shall not be responsible or answerable for any loss, damage or liability etc. caused in relation to/arising out of the use of the content. 